\title{
Effect of Audiovisual on Pregnant Women Knowledge of Stunting
}

\author{
$1^{\text {st }}$ Ima Sukmawati \\ Stikes Muhamadiyah Ciamis \\ Ciamis, Indonesia \\ imasukmawati90@yahoo.com \\ $4^{\text {th }}$ Heni Marliani \\ Stikes Muhamadiyah Ciamis \\ Ciamis, Indonesia
}

\author{
$2^{\text {nd }}$ Dedi Supriadi \\ Stikes Muhamadiyah Ciamis \\ Ciamis, Indonesia \\ $5^{\text {th }}$ Rosmiati \\ Stikes Muhamadiyah Ciamis \\ Ciamis, Indonesia
}

\author{
$3^{\text {rd }}$ Yanti Srinayanti \\ Stikes Muhamadiyah Ciamis \\ Ciamis, Indonesia \\ $6^{\text {th }}$ Dwi Novianti Sugiharti \\ Stikes Muhamadiyah Ciamis \\ Ciamis, Indonesia
}

\begin{abstract}
The number of stunting sufferers in Indonesia is quite high. Lack of knowledge and awareness of mothers towards balanced nutrition during pregnancy is one of the triggers for stunting. The Ciamis District Health Office (2017) found that the prevalence of stunting in the Baregbeg Community Health Center (PUSKESMAS) is $17 \%$ and has increased in 2018 to $23.19 \%$. The purpose of this study was to determine the effect of audiovisual on the level of knowledge of pregnant women about stunting in Sukamulya Village, Baregbeg District. The method used is using the type of Pre-Experimental Design research with one group pretest and posttest design in 53 Trimester I to III pregnant women who visit Posyandu Sukamulya Village. The total population of 53 people with a total sampling method. The research instrument used a questionnaire that was processed by the Wilcoxon test using SPSS. The results of the study based on the level of knowledge before being given audio visual included good category as many as 16 people (30.2\%), enough categories as many as 25 people $(\mathbf{4 7 . 2 \%})$, and fewer categories were 12 people $(22.6 \%)$. After being given audiovisual based on the level of knowledge in all respondents categorized as good as many as 53 people (100\%). Wilcoxon test obtained p-value $0,000<\alpha, 0.05$, it can be concluded that $\mathrm{HO}$ is rejected and $\mathrm{Ha}$ is accepted so that there is an effect of giving audiovisual to the knowledge of pregnant women about stunting. The provision of audiovisual (video) can increase the mother's knowledge because audio-visual media is an educational medium which in its use can stimulate the senses of sight and hearing that can increase perception, be able to increase knowledge and improve memory. So that it can indirectly improve the memory of pregnant women for the long term. Conclusion: there is an audiovisual effect on the knowledge of pregnant women about stunting in Sukamulya Village, Baregbeg District.
\end{abstract}

Keywords-Audiovisual, Pregnant Women, Knowledge, Stunting

\section{INTRODUCTION}

Globally about 1 in 4 toddlers experience stunting. occurrence Stunting is common in children aged 12-36 months with a prevalence of $41.5 \% 38,3-$ [1]. This trend is expected to reach $21.8 \%$ or 142 million in 2020 . Stunting is a nutritional status based on height index according to age. Basic Health Research [2] shows that an increase in the prevalence of Health stunting in Indonesia from $36.8 \%$ in 2007 to $37.2 \%$ (almost 9 million) of children under five experienced stunting in 2013, meaning that 1 in 3 Indonesian children is classified as short [3]
Indonesia is a country with the prevalence of stunting fifth largest.

The West Java National Population and Family Planning Agency (BKKBN) reported the prevalence of stunting in West Java had reached $29.2 \%$ in 2017. The figure is in the middle range, while above 30 percent means high prevalence. The case of stunting is very influential in economic growth. The Ciamis Health Office said the stunting rate was in the Baregbeg health center (PUSKESMAS) with a prevalence of $17 \%$ in 2017 while in 2018 it was 23.19 so there was an increase in the number of stunting in the Baregbeg sub-district, where Sukamulya Village was the place with the highest stunting rate in the Baregbeg sub-district, which was as much as 145 people $(23.6 \%)$

The impact of stunting causes impaired cognitive development, increased risk of infectious diseases and even death. Stunting can reduce school performance and life productivity [4]. One way to overcome the problem of stunting is to improve the nutritional situation in the First 1000 Days of Life (HPK) which will reduce infant and toddler mortality, improve children's growth and development, physical, mental, social, work productivity and academic achievement. Another factor is good nutritional intake where knowledge plays the most role. Mother's knowledge has a major influence on the prevention of stunting in children.

Prevention Stunting policies based on long-term food and nutrition program policies are formulated in Law No.17 of 2007 concerning the National Long-Term Development Plan (RPJPN) 2005 - 2025. Multi-sectoral approaches include production, processing, distribution, and food consumption, with adequate nutrition, balanced, and guaranteed safety. Long-term development is carried out in stages over five years, formulated in the National Medium Term Development Plan (RPJMN) document stipulated in the Presidential Regulation where nutrition programs are more focused on pregnant women to children aged 2 years [3].

An important effort made by the government is health promotion. Health promotion is used as an approach to delivering messages so that information is easily accepted and understood. One of the interventions is using audiovisual media. Audio-visual media is one method that can stimulate the community, especially 
families, to be able to become innovators in their household environment [5].

\section{RESEARCH METHODS}

This study aims to determine the effect of audiovisual on pregnant mothers' knowledge of stunting in Sukamulya Village, Baregbeg District. When the study was conducted on May 1 - 112019 in 9 integrated service place (POSYANDU) Sukamulya Village, Baregbeg District. This type of research uses Pre-Experimental Design with research one group pretest and posttest design involving one group of subjects. The population is all pregnant women in Sukamulya Village, Baregbeg Subdistrict, as many as 53 people, which are calculated based on the number of Trimester I to III pregnant women. The sampling technique is using method Non-probability sampling, which is a total sampling of 53 people. Data analysis uses statistical tests Wilcoxon with the help of the Statistical Software. The instrument used to measure the knowledge of pregnant women is a questionnaire or list of questions with multiple choice.

\section{RESEARCH RESULTS}

TABLE 1. FREQUENCY DISTRIBUTION CHARACTERISTICS OF RESPONDENTS BASED ON MATERNAL AGE MATERNAL

\begin{tabular}{|c|c|c|}
\hline Age & Frequency (person) & Percentage (\%) \\
\hline $17-25$ & 21 & 39.6 \\
\hline $26-35$ & 22 & 41.5 \\
\hline $36-45$ & 10 & 18.9 \\
\hline Total & 53 & 100.0 \\
\hline
\end{tabular}

Results from table 1 note that the highest maternal age is in the age range 26-35 years as many as 22 people $(41.5 \%)$.

TABLE 2. FREQUENCY DISTRIBUTION CHARACTERISTICS OF RESPONDENTS BASED ON MOTHER'S EDUCATION MOTHER'S

\begin{tabular}{|c|c|c|}
\hline Education & Frequency (people) & Percentage (\%) \\
\hline Elementary & 33 & 62.3 \\
\hline Intermediate & 19 & 35.8 \\
\hline High & 1 & 1.9 \\
\hline Total & 53 & 100 \\
\hline
\end{tabular}

Results from table 2 note that the highest level of maternal education is 33 people basic education $(62,3 \%)$ and the lowest is a tertiary education of 1 person $(1.9 \%)$.

TABLE 3. FREQUENCY DISTRIBUTION OF CHARACTERISTICS OF RESPONDENTS BASED ON WORKING STATUS OF MOTHER

\begin{tabular}{|c|c|c|}
\hline Worked Mother & Frequency (people) & Percentage (\%) \\
\hline Civil Servants & 1 & 1.9 \\
\hline Traders & 5 & 9.4 \\
\hline Farmers & 1 & 1.9 \\
\hline Housewife & 46 & 86.8 \\
\hline Total & 53 & 100.0 \\
\hline
\end{tabular}

Results from table 3 note the employment status of the majority of non-working mothers or housewives the stairs as many as 46 people $(86.8 \%)$.

TABLE 4. FREQUENCY DISTRIBUTION CHARACTERISTICS OF RESPONDENTS BASED ON FAMILY INCOME

\begin{tabular}{|l|c|c|}
\hline Income & $\begin{array}{c}\text { Frequency } \\
\text { (people) }\end{array}$ & $\begin{array}{c}\text { Percentage } \\
(\%)\end{array}$ \\
\hline Less & 21 & 39.6 \\
\hline Medium & 23 & 43.4 \\
\hline High & 9 & 17.0 \\
\hline Total & 53 & 100 \\
\hline
\end{tabular}

Results from table 4 note that family income per month is predominantly in the middle category of 23 people $(43.4 \%)$.

\section{A. Univariate Analysis}

TABLE 5. FREQUENCY DISTRIBUTION OF PREGNANT WOMEN 'S KNOWLEDGE LEVELS ABOUT STUNTING BEFORE AND AFTER AUDIOVISUAL TREATMENT

\begin{tabular}{|c|c|c|c|c|c|c|c|}
\hline \multirow{2}{*}{ No } & \multirow{2}{*}{ Category } & \multicolumn{3}{|c|}{ Pretest } & \multicolumn{3}{|c|}{ Posttest } \\
\hline & & $\mathrm{f}$ & $\%$ & Mean & $\mathrm{F}$ & $\%$ & Mean \\
\hline 1 & Good & 16 & 30.2 & \multirow{3}{*}{9.72} & 53 & 100 & \multirow{3}{*}{145.53} \\
\hline 2 & Enough & 25 & 47.2 & & 0 & & \\
\hline 3 & Less & 12 & 22.6 & & 0 & & \\
\hline & Total & 53 & 100.0 & & 53 & 100.0 & \\
\hline
\end{tabular}

The results of table 5 can be seen that the level of knowledge of pregnant women about Stunting before being given the audiovisual (pretest) category is highest in the category of enough as many as 25 people (47.2\%), good categories were 16 people $(30.2 \%)$ and fewer categories were 12 people $(22.6 \%)$. Whereas after being given audiovisual (posttest), it is in the good category of 53 people $(100 \%)$ with an average score of 9.72 pretests and 14.53 posttest.

\section{B. Bivariate Analysis}

TABLE 6. TEST RESULTS PREGNANCY DIFFERENT KNOWLEDGE LEVEL ABOUT STUNTING BEFORE AND AFTER AUDIOVISUAL TRETMENT, USING THE WILCOXON TEST

\begin{tabular}{|c|c|c|c|}
\hline & $\mathrm{N}$ & Presentation (\%) & \multirow{2}{*}{$\mathrm{p}$-Value } \\
\hline Decreases & 0 & 0 & \multirow{2}{*}{0,000} \\
\cline { 1 - 2 } Increases & 53 & 100 & \\
\hline Fixed & 0 & 0 & \\
\hline Total & 53 & 100.0 & \\
\hline
\end{tabular}

The results from table 6 show that all respondents experienced an increase in knowledge. This value indicates the value posttest is greater than the pretest with an average increase of 4.81.test results Wilcoxon obtained a p-value of 0,000 then $<\alpha=0.05$ and can be concluded 
that Ho was rejected and Ha was accepted. This means that there is an effect of giving audiovisual knowledge of pregnant women about stunting in and all respondents experienced an increase in knowledge scores after being given audiovisual.

\section{DISCUSSION}

A. The description of the knowledge of pregnant women about stunting before being given audiovisual in Sukamulya Village, Baregbeg Subdistrict

The results of the univariate analysis showed that the level of knowledge before being given audiovisual to 53 respondents obtained the highest results in the sufficient category of 25 people (47.2\%), a good category of 16 people $(30.2 \%)$ and less than 12 people $(22.6 \%)$. Factors causing the lack of information in pregnant women due to low education. The results showed that pregnant women with sufficient knowledge, namely elementary school education as many as 17 people (77.2\%) from 22 respondents. In line with Notoatmodjo [6] states that low education will hamper the development of information. Nurussalam [7] also stated that the lower level of education of a person, it caused the lack of knowledge possessed.

Knowledge of pregnant women can also be influenced by work. The results of the study in table 3 show that out of 53 respondents 46 people $(86.8 \%)$ were either unemployed or housewives. This is because of the 25 people $(47.2 \%)$, said they had never received information related to stunting from various sources. This statement is supported by Wawan \& Dewi's theory [8] that the work environment can form a knowledge due to the exchange of information between friends in the work environment. The work environment indirectly contributes to influencing one's level of knowledge, because work is closely related to social and cultural interaction factors. While social and cultural interactions are closely related to the process of information exchange. And this will certainly affect the level of knowledge.

\section{B. Description of pregnant women knowledge about stunting after being given audiovisual in Sukamulya Village, Baregbeg Subdistrict}

Based on the analysis in Table 5, increasing pregnant women's knowledge about stunting, there are differences in mean values between before and after audiovisual education. At the time of the pretest (before being given audiovisual) value 9.72 mean. At the posttest (after being given audiovisual) the mean value was 14.53 where there was a mean difference of 4.81 . This means that an increase in respondents' knowledge after being given an audiovisual about knowledge stunting. The results of the study can be seen in Table 5 shows that after counseling using audiovisual knowledge the respondents experienced an increase, with a good category of 53 people $(100 \%)$. There is a significant difference between prior and after audiovisual knowledge. The statistical results with the test Wilcoxon on the SPSS 16.0 computerized system are listed in table 6 , the p-value of 0,000 then p-value $<\alpha=$ 0.05 so it can be concluded that Ho was rejected and $\mathrm{Ha}$ was accepted.

Increased knowledge of pregnant women about stunting comes from information provided through audiovisual media that researchers do. It was concluded that the provision of health information using audiovisual proven to affect increasing knowledge of pregnant women. According to HS, Sulaeman, \& Idriani [9], audiovisual media is an educational aid that in its use stimulates the senses of sight and hearing. While Arsyad [10] states that audiovisual media is an educational tool that has sound and image elements, it is to improve perception, increase knowledge and memory.

In line with Wicaksono's research [11] that audiovisual has a higher influence compared to other media with $\mathrm{p}<0.05$. It was concluded that audiovisual is the best medium to increase knowledge, attitudes, and behavior. Another factor that influences knowledge is the age of pregnant women. According to Mubarak [12], with increasing age, someone will experience changes in physical and psychological aspects (mental). In psychological or mental aspects, the level of thinking of a person becomes more developed and mature.

The results of the study listed in table 1 show that the majority of pregnant women in the age range of 19-25 years were 21 people $(39.6 \%)$ included in the late adolescence category. Most respondents were 22-year-old pregnant women, describing a person's maturity, both physical and social. According to the Ministry of Health of the Republic of Indonesia [13] that the age of 17-25 years is the end of adolescence or the transition from adolescence to adulthood followed by the development of hormones in someone who turns them into physically more mature, open and organized thoughts.

The results of the researchers note that the average difference of knowledge before and after being given audiovisual increased very significantly. It can be seen by providing education using audiovisual media proven that there is an influence that can increase the mother's knowledge about stunting. Audiovisual is an effective tool because the media is interesting and unique as there are animations so that mothers easily understand the contents or material delivered. So that it can indirectly improve the respondent's memory for the long term.

C. Audiovisual influence on the knowledge of pregnant women about stunting in Sukamulya Village, Baregbeg District

Different test results in table 6 show an increase in knowledge of pregnant women about stunting, which is a very significant influence between before and after being given audiovisual. The Value probability of the test Wilcoxon is 0,000 , then the $\mathrm{p}$-value $<\alpha=0.05$ can be concluded that $\mathrm{Ha}$ is accepted and Ho is rejected. This shows that counseling using audiovisual about stunting in pregnant women causes different levels of knowledge (increased) compared to before counseling with given audiovisual. This means that counseling using audiovisual 
is very effective against increasing knowledge of stunting in pregnant women.

The results of the study are in accordance with Pragita, Purwandari, \& Sulistyorini [14] that there are differences in influence in health education, the media used is audiovisual which combines the media that can be heard as well as can be seen, so that communication can be captured in two senses, namely hearing and vision. This increases motivation and communication in learning to be interesting and understandable.

The use of intervention media to conduct health education among others must meet several aspects so that the intervention media are easily accepted and understood by the target group. Print media as an intervention media used among them must generate interest in the target group to read the message contained therein.

The success of the implementation of counseling by using audiovisual is caused by the readiness of researchers in preparing counseling material. Educational media such as audiovisuals can convey health knowledge well because the tool is used to facilitate the reception of health messages for the community, especially for pregnant women.

\section{CONCLUSION}

The level of knowledge of pregnant women before being given audiovisual about Stunting is largely in the category of sufficient knowledge, after being given audiovisual all respondents included in either category. There is a significant influence on the level of knowledge between before and after the audiovisual media is given about stunting so that it can be concluded that there is an increase in knowledge in pregnant women.

\section{REFERENCES}

[1] Margawati A \& Astuti A M 2018 Pengetahuan ibu, pola makan dan status gizi pada anak stunting usia 1-5 tahun di Kelurahan Bangetayu, Kecamatan Genuk, Semarang Jurnal Gizi Indonesia, 6(2), 82-89 https://doi.org/e-ISSN : 2338-3119, p-ISSN : 18584942

[2] RISKESDAS 2017 Profil Kesehatan Kabupaten Ciamis Ciamis

[3] Kementrian Kesehatan Republik Indonesia 2017 Profil Kesehatan Republik Indonesia Tahun 2017. Jakarta: Kementrian Kesehatan Republik Indonesia

[4] Okky, A \& Rohmawati, N. (2015). Faktor-faktor yang Mempengaruhi Kejadian Stunting pada Anak Balita di Wilayah Pedesaan dan Perkotaan ( The Factors Affecting Stunting on Toddlers in Rural and Urban Areas ). E-Jurnal Pustaka Kesehatan, 3(1)

[5] Susilo Wirawan, Lalu Khairul Abdi, N K 2014 Pengaruh penyuluhan dengan media audio visual dan konvensional terhadap pengetahuan ibu anak balita tidak naik berat badan (t1 dan t2) di wilayah pusk. Penimbung kabupaten lombok barat (Ntb). Jurnal Kesehatan Prima, I(2), 1265-1278. https://doi.org/1978 13334

[6] Notoatmodjo S 2014 Ilmu Perilaku Kesehatan (2nd ed.) Jakarta: Rineka Cipta

[7] Nursalam 2011 Konsep Dan Penerapan Metodologi Penelitian Ilmu Keperawatan Jakarta: Salemba Medika

[8] Wawan A \& Dewi M 2011 Teori dan Pengukuran Pengetahuan, Sikap dan Perilaku Manusia, Cetakan II.Yogyakarta: Nuha Medika.

[9] HS, S. A. S., Sulaeman, S., \& Idriani 2018 pengaruh paket edukasi tanda bahaya kehamilan melalui media booklet, audiovisual dan kombinasi terhadap pengetahuan dan sikap ibu hamil Wacana Kesehatan, 3(2), 356-372 https://doi.org/2541-
6251

[10] Arsyad, A 2014 Media Pembelajara.Jakarta: PT Rajagrafindo Persada

[11] Wicaksono D 2016 pengaruh media audio-visual mp-asi terhadap pengetahuan, sikap dan perilaku ibu baduta di puskesmas kelurahan johar baru. Jurnal Penelitian Dan Pengabdian Masyarakat, 291-298 https://doi.org/1693-699

[12] Mubarak W I 2011 Promosi Kesehatan Kebidanan Jakarta: Salemba Medika

[13] Departemen Kesehatan RI 2016 Profil Kesehatan Indonesia 2015 Jakarta

[14] Pragita, R. R., Purwandari, R., \& Sulistyorini, L. (2018). Pengaruh pendidikan kesehatan metode stratagem dengan media audiovisual terhadap pengetahuan kesehatan reproduksi remaja. The Indonesian Journal Of Health Science, 16(September). https://doi.org/2476-9614 